\title{
Idiopathic very late-onset cerebellar ataxia: a Brazilian case series
}

\author{
Ataxia cerebellar idiopática com início muito tardio: uma série de casos brasileiros \\ Hélio A. G. Teive', Mariana Moscovich'1, Adriana Moro', Marina Farah', Walter O. Arruda', Renato P. Munhoz
}

\begin{abstract}
The authors present a Brazilian case series of eight patients with idiopathic very-late onset (mean 75.5 years old) cerebellar ataxia, featuring predominantly gait ataxia, associated with cerebellar atrophy. Method: 26 adult patients with a diagnosis of idiopathic late onset cerebellar ataxia were analyzed in a Brazilian ataxia outpatient clinic and followed regularly over 20 years. Among them, 8 elderly patients were diagnosed as probable very late onset cerebellar ataxia. These patients were evaluated with neurological, ophthalmologic and Mini-Mental Status examinations, brain MRI, and EMG. Results: $62.5 \%$ of patients were males, mean age was 81.9 years-old, and mean age of onset was 75.5 years. Gait cerebellar ataxia was observed in all patients, as well as, cerebellar atrophy on brain MRI. Mild cognitive impairment and visual loss, due to macular degeneration, were observed in 50\% of cases. Chorea was concomitantly found in 3 patients. Conclusion: We believe that this condition is similar the one described by Marie-Foix-Alajouanine presenting with mild dysarthria, associated with gait ataxia, and some patients had cognitive dysfunction and chorea.
\end{abstract}

Keywords: late-onsetcerebellarataxia, cerebellaratrophy, idiopathic late-onsetcerebellarataxia,cerebellaratrophy ofMarie-Foix-Alajouanine.

\section{RESUMO}

Os autores apresentam uma série de casos incluindo oito pacientes com ataxia cerebellar de início muito tardio (média de 75,5 anos de idade) apresentando ataxia de marcha, associada à atrofia cerebelar. Método: 26 pacientes adultos com diagnóstico de ataxia cerebelar de início tardio idiopática foram analisados ambulatorialmente e acompanhados regularmente ao longo de 20 anos. Destes, oito pacientes idosos foram diagnosticados como provável ataxia cerebelar início muito tardio. Os pacientes foram submetidos a um exame neurológico completo, avaliação cognitive e oftalmológica assim como ressonância magnética do cérebro e eletroneuromiografia tambem foram realizados. Resultados: $62,5 \%$ dos pacientes eram do sexo masculino, com idade média de 81,9 anos, com média de idade de início aos 75,5 anos. Ataxia cerebelar predominante de marcha foi observada em todos os pacientes, bem como, a atrofia cerebelar na ressonância magnética cerebral. Comprometimento cognitivo leve e perda visual, devido à degeneração macular, foram observados em $50 \%$ dos casos. Coréia foi encontrada em 3 pacientes. Conclusão: Acreditamos que esta condição é semelhante à descrita por Marie-Foix-Alajouanine apresentando disartria leve, associada a ataxia de marcha, disfunção cognitiva e coréia.

Palavras-chave: ataxia cerebelar de início tardio, atrofia cerebelar, ataxia cerebelar de início tardio idiopática, atrofia cerebelar de Marie-Foix-Alajouanine.

Idiopathic sporadic cerebellar ataxia comprehends a group of neurodegenerative, non-hereditary disorders, including multiple system atrophy cerebellar type (MSA-C), and idiopathic late onset cerebellar ataxia (ILOCA) ${ }^{1,2}$. ILOCA represents an obscure group of sporadic cases of late onset cerebellar ataxia, without adequate clinical, pathological, and genetic definition, described by Harding in $1981^{3,4}$. Late-onset cerebellar atrophy of Marie-Foix-Alajouanine is a sub-group of ILOCA patients with very late onset (IVLOCA) ${ }^{5}$. The objective of this study is to analyze the follow-up of 8 Brazilian patients with IVLOCA.

\section{METHOD}

Clinical and paraclinical findings of 26 adult patients with a diagnosis of ILOCA were analyzed in a Brazilian ataxia outpatient clinic and followed regularly over 20 years. Among them, 8 elderly patients were diagnosed as probable IVLOCA. These patients were evaluated with neurological, ophthalmologic and Mini-Mental Status examinations, brain MRI, and EMG. Genetic testing for Friedreich's ataxia, Spinocerebellar ataxias (SCAs) types 3, 6, 17 (in three cases), Huntington's disease in three cases

\footnotetext{
1Universidade Federal do Paraná, Hospital de Clínicas, Departamento de Medicina Interna, Unidade de Distúrbios do Movimento, Curitiba PR, Brazil; ¿University of Toronto, Toronto Western Hospital, Movement Disorders Centre, Toronto ON, Canada.

Correspondence: Hélio A. G. Teive; Rua General Carneiro 1103/102;80060-150 Curitiba PR, Brasil; E-mail:hagteive@mps.com.br

Conflict of interest: There is no conflict of interest to declare.

Received 04 March 2015; Received in final form 28 May 2015; Accepted 16 June 2015.
} 
with chorea, and Fragile X-associated tremor ataxia syndrome (FXTAS - in three patients). Diagnosis of probable REM sleep behavior disorder (RBD) was based on clinically validated criteria.

\section{RESULTS}

In this case series of IVLOCA, $62.5 \%$ of patients were males, mean age was 81.9 years-old, and mean age of onset was 75.5 years. Gait cerebellar ataxia was observed in all patients, as well as, cerebellar atrophy on brain MRI. Brain MRI also demonstrated mild signs of microangiopathy in three patients. There was no incoordination in the upper limbs, and mild dysarthria was found in $50 \%$ of patients. Mild choreiform movements were detected in three patients. There were no pyramidal signs and no dysautonomia. There was no family history of ataxia. Genetic tests for Friedreich's ataxia, SCAs 3, 6, and 17, and Huntington's disease and FXTAS, were negative. In two patients, mild sensory peripheral neuropathy was diagnosed on EMG. None had RBD. Visual loss, with macular degeneration, and amnestic mild cognitive impairment (MCI) were detected in four (50\%) cases each (Table).

\section{DISCUSSION}

IVLOCA represents a controversial entity, representing a subgroup of ILOCA cases. Currently, alternative terms have been used to describe to this group of patients, such as sporadic adult onset ataxia of unknown etiology (SAOA), or idiopathic late-onset pure cerebellar ataxia (ILOPCA), among others ${ }^{1,2,6,7,8}$. MSA-C represents the main differential diagnosis of ILOCA ${ }^{8,9}$. This group of non-hereditary degenerative ataxias needs to be differentiated from hereditary ataxias (with late-onset and no familial history), and acquired ataxias, which are due to exogenous or endogenous non-genetic causes. ${ }^{1}$ In this Brazilian case series of eight patients with IVLOCA, besides gait cerebellar ataxia, with cerebellar atrophy on brain MRI, and very late-onset (mean age of onset 75.5 years), half of all cases also presented with visual loss due to macular degeneration, and amnestic MCI. Additionally chorea was found in three patients. The mean time of follow-up was 5 years, with slow progression, and mild phenotype (predominantly gait ataxia). There no clues to alternative diagnoses, including MSA. We believe that this condition is similar the one described by Marie-Foix-Alajouanine, in 1922, named "Atrophie cérébelleuse tardive a predominance corticale", cerebellar cortical atrophy (CCA), or pure cerebello-olivary degeneration ${ }^{5}$. In this condition with late-onset, there was mild dysarthria, associated with gait ataxia, and some patients had cognitive dysfunction and chorea ${ }^{5}$. Fox et al published in 2003 a case report of this entity, in a patient with a sporadic, late-onset progressive cerebellar ataxia plus cognitive decline and chorea, with CCA on neuropathological examination. ${ }^{10}$ The main limitation of our study is its essentially clinical background, with no neuropathological confirmation with a limited number of genetic diseases excluded.

Table. Idiopathic very late-onset cerebellar ataxia - demographic data.

\begin{tabular}{|c|c|c|c|c|c|c|c|c|c|}
\hline Case & Gender/Age/Age of onset & Gait ataxia & $\mathrm{MCl}$ & Chorea & Ophthalmology Examination & Brain MRI & RBD & EMG & SARA \\
\hline 1 & $F / 91 / 83$ & + & - & - & - & Cerebellar atrophy & - & SPN & 8 \\
\hline 2 & $F / 80 / 75$ & + & + & - & - & Cerebellar atrophy & - & SPN & 5 \\
\hline 3 & $\mathrm{~F} / 88 / 82$ & + & + & + & + & Cerebellar atrophy & - & - & 10 \\
\hline 4 & $\mathrm{M} / 85 / 80$ & + & + & + & - & Cerebellar atrophy + brain microang. & - & - & 4 \\
\hline 5 & $\mathrm{M} / 80 / 77$ & + & + & + & + & Cerebellar atrophy + brain microang. & - & - & 8 \\
\hline 6 & $\mathrm{M} / 82 / 75$ & + & - & - & + & Cerebellar atrophy & - & - & 9 \\
\hline 7 & $\mathrm{M} / 75 / 71$ & + & - & - & + & Cerebellar atrophy & - & - & 5 \\
\hline 8 & $\mathrm{M} / 73 / 70$ & + & - & - & - & Cerebellar atrophy + brain microang. & - & - & 11 \\
\hline
\end{tabular}

F: Female; M: Male; Age/Age of onset: Years; +: Present; -: Absent; MCl: Mild Cognitive Impairment; Ophthalmology examination: Macular degeneration; Brain MRI: Brain Magnetic Resonance Imaging; brain microang.: Brain Microangiopathy; RBD: REM Sleep Behavior Disorder; EMG: Electromyography; SPN: Sensory Peripheral Neuropathy; SARA: Scale for the Assessment and Rating of Ataxia.

\section{References}

1. Klockgether T. Sporadic ataxia with adult onset: classification and diagnostic criteria. Lancet Neurol. 2010;9(1):94-104. doi:10.1016/S1474-4422(09)70305-9

2. Kerber KA, Jen JC, Perlman S, Baloh RW. Late-onset cerebellar ataxia: differentiating those with and without identifiable mutations. J Neurol Sci. 2005;238(1-2): 41-5. doi:10.1016/j.jns.2005.06.006
3. Harding AE. The hereditary ataxias and related disorders. Edinburgh: Churchill Livingstone; 1984.

4. Harding AE. "Idiopathic" late onset cerebellar ataxia: a clinical and genetic study of 36 cases. J Neurol Sci. 1981;51(2):259-71. doi:10.1016/0022-510X(81)90104-0 
5. Marie P, Foix C, Alajouanine T. De l'atrophie cérébelleuse tardive à prédominance corticale. Revue Neurol (Paris). 1922; 2:849-85, 1082-111.

6. Schöls L, Szymanski S, Peters S, Przuntek H, Epplen JT, Hardt C et al. Genetic background of apparently idiopathic sporadic cerebellar ataxia. Hum Genet. 2000;107(2):132-7. doi:10.1007/s004390000346

7. Abele M, Bürk K, Schöls L, Schwartz S, Besenthal I, Dichgans $J$ et al. The aetiology of sporadic adult-onset ataxia. Brain. 2002;125(5):961-8. doi:10.1093/brain/awf107
8. 8. Lin DJ, Hermann KL, Schmahmann JD. Multiple system atrophy of the cerebellar type: clinical state of the art. Mov Disord. 2014;29(3):294-304. doi:10.1002/mds.25847

9. 9. Gilman S, Little R, Johanns J, Heumann M, Kluin KJ, Junck L et al. Evolution of sporadic olivopontocerebellar atrophy into multiple system atrophy. Neurology. 2000;55(4):527-32. doi:10.1212/WNL.55.4.527

10. 10. Fox SH, Nieves A, Bergeron C, Lang AE. Pure cerebello-olivary degeneration of Marie, Foix, and Alajouanine presenting with progressive cerebellar ataxia, cognitive decline, and chorea. Mov Disord. 2003;18(12):1550-4. doi:10.1002/mds.10606 